\title{
Bibliometric Analysis of the Research on (in)equality of Opportunities in Education
}

\section{Mücella Savaş Yalçın¹}

\section{Didem Koşar ${ }^{2}$}

\section{Abstract}

Type/Tür:

Research/Araştırma

Received/Geliş Tarihi: November

6/ 6 Kasim 2020

Accepted/Kabul Tarihi: June 14/

14 Haziran 2021

Page numbers/Sayfa No: 1194-1213

Corresponding

Author/Illetişimden Sorumlu Yazar: mucella.savas@atauni.edu.tr

\section{$\checkmark$ iThenticate}

This paper was checked for plagiarism using iThenticate during the preview process and before publication. / Bu çalışma ön inceleme sürecinde ve yayımlanmadan önce iThenticate yazılımı ile taranmıştır.

Copyright $@ 2017$ by Cumhuriyet University, Faculty of Education. All rights reserved.

\begin{abstract}
In this study, it is aimed to systematically examine the development of publications on (in)equality of opportunity in education, over time. The metadata obtained from the Web of Science database was analyzed using bibliometric methods in order to see the change of publications between 1974 and 2020 over time. VOSviewer is used as popular visualization tools to process bibliographic data. 505 articles in the Web of Science (WoS) database were examined and the most cited articles, the most influential publications, and authors were determined, in addition to the distribution of the number of publications and citations by years. Co-authorship analysis was carried out to establish a visual map of the cooperation network in the field, and collaborations between authors, countries, and institutions were tried to be determined. In addition, in order to reveal the intellectual structure of the field, co-citation analysis was applied and the dominant writers and publications were tried to be determined. According to the results obtained, the number of publications and citations on (in)equality of opportunity in education has increased significantly over the years. However, the relationship between the authors, institutions, and countries appears to be weak in the field. Cooperation between authors and institutions is very weak, and most of the collaborating institutions are located in the USA. As a result of this research, since the researches in the field are conducted independently, it reveals that the publications about the (in)equality of opportunity in education will be made more comprehensive and in cooperation in the future.
\end{abstract}

Keywords: (in)equality of educational opportunities, bibliometric analysis, Web of Science (WoS) database, VOSviewer, science mapping

\section{Suggested APA Citation/Önerilen APA Atıf Biçimi:}

Savaş-Yalçın, M., \& Koşar, D. (2021). Bibliometric analysis of the research on (in)equality of opportunities in education. Cumhuriyet International Journal of Education, 10(3), 1194-1213. http://dx.doi.org/10.30703/cije.822317

\footnotetext{
1 Arş.Gör., Atatürk Üniversitesi, Kazım Karabekir Eğitim Fakültesi, Eğitim Bilimleri Bölümü, Erzurum/Türkiye Res. Asst., Atatürk Universty, Faculty of Kazım Karabekir Education, Departman of Educational Sciences, Erzurum/Turkey e-mail: mucella.savas@atauni.edu.tr ORCID ID: orcid.org/0000-0002-0226-999X
}

\footnotetext{
2 Doç. Dr., Hacettepe Üniversitesi, Eğitim Fakültesi, Eğitim Bilimleri Bölümü, Ankara/Türkiye Assoc.Prof., Hacettepe Universty, Faculty of Education, Departman of Educational Sciences, Ankara/Turkey e-mail: didemkosar@hacettepe.edu.tr ORCID ID: orcid.org/0000-0003-4959-1094
} 


\title{
Eğitimde Fursat Eşit(siz)liği ile ilgili Araştırmaların Bibliyometrik Analizi
}

\begin{abstract}
Öz
Bu çalışmada, eğitimde fırsat eşit(siz)liği ile ilgili yayınların zaman içindeki gelişiminin sistematik olarak incelenmesi amaçlanmıştır. 1974-2020 yılları arasındaki yayınların zaman içindeki değişimini görmek için Web of Science veritabanından elde edilen meta veriler bibliyometrik yöntemlerle incelenmiştir. Bibliyografik verileri işlemek için popüler görselleştirme aracı olan VOSviewer kullanılmıştır. Web of Science (WoS) veri tabanında yer alan 505 makale incelemeye alınıp, yıllara göre yayın ve atıf sayılarının dağılımının yanı sıra en çok atıf alan makaleler, en etkili yayınlar ve yazarlar belirlenmiştir. Sahadaki işbirliği ağının görsel bir haritasını oluşturmak için ortak yazarlık analizi yapılarak yazarlar, ülkeler ve kurumlar arasındaki işbirlikleri belirlenmeye çalışılmıştır. Ayrıca alanın entelektüel yapısını ortaya çıkarmak için ortak atıf analizi uygulanarak baskın yazar ve yayınlar belirlenmeye çalışılmıştır. Elde edilen sonuçlara göre, eğitimde fırsat eşit(siz)liği ile ilgili yayın ve atıf sayısı yıllar içerisinde önemli ölçüde artmıştır. Ancak bu alanda yazarlar, kurumlar ve ülkeler arasındaki ilişki zayıf görünmektedir. Birçok yazar birbirinden bağımsız olarak çalışmış ve kurumlar arasındaki işbirliği yazar işbirliğine bağlı olarak çok zayıf olmakta, işbirliği yapan kurumların çoğu ABD'de sınırları içerisinde kalmaktadır. Ülkeler çok az işbirliği içerisinde olup, çoğu coğrafi konum bakımından birbirinden farklı yerlerdedir. Alanın yapısına bakıldığında, ortak atıf yapılan yazar ve çalışmalar eğitimde fırsat eşitliğiyle ilgili en temel referans kaynaklardır. Bu araştırmanın sonucunda, eğitimde fırsat eşit(siz)liği ile ilgili araştırmaların çoğunun bağımsız yürütüldüğü ortaya çıkmıştır. $\mathrm{Bu}$ durum alanda yapılacak diğer araştırmaların daha kapsamlı ve işbirliği içerisinde yapılmasını gözler önüne sermektedir.
\end{abstract}

Anahtar Kelimeler: Eğitim fırsat eşit(siz)liği, bibliyometrik analiz, Web of Science (WoS) veritabanı, VOSviewer, bilim haritalama

\section{Introduction}

Ensuring (in)equality of educational opportunities is one of the most controversial areas in education policy research. In addition to the benefits that education brings to the individual and society, the fact that it provides intergenerational mobility (McMahon, 2000; Mihai, Titan, \& Manea 2015; Woessmann, 2004) led to the implementation of arrangements and practices to cover all social segments of education. However, the whole segment of society did not benefit equally from the opportunities for education, resulting in increased social inequalities. Therefore, priorities for eliminating inequalities in education have become an important component of education policy. Accordingly, many studies, and examinations have been carried out in this area, and they are tried to make determinations about the reason, source and solution of inequalities (Borman, \& Dowling 2010; Coleman, 1968; Gamoran, \& Long, 2006 Hanushek, \& Kain 1972; OECD, 2016, 2018).

Research and discussions on (in)equality of educational opportunities started with the construction of a meritocratic discourse and continued with the idea that the distribution of resources in education should be distributed equally to all members of the society. Thus, individuals will have equal chances in competitive conditions, so they can compete equally in living conditions (Arneson, 2009). However, in the next process, researches and discussions have progressed by expanding to from equality of conditions to equality an understanding of equality of results, revealing that equalizing educational inputs cannot equalize student outcomes (Ünal, \& Özsoy, 
1999). In the last fifteen years, important literature has emerged that aims to evaluate the degree of inequality of opportunity created by equality opportunity policies, as well as evaluating the effects of social and economic policies on equality of opportunity in different countries (Peragine, \& Ferreira, 2015).

The literature on (in)equality of opportunities in education has increased exponentially in recent years. In this way, the knowledge base of the area has been enlarged to a large extent, and it has become difficult to see the picture of the area. The aim of the research is to fill the gap in this field based on the systematic review of international publications on equal opportunities in education. On the other hand, examining the progress of a field in time helps the development of the field (Feehan, Gragg II, Havener, \& Kester, 1987). Therefore, it can increase the interaction of other researchers by showing researchers in which fields there are gaps and what kind of contributions they can provide.

In the scientific world, it is considered important to advance a certain research line to synthesize past researches. Various research methods are applied for this. One of these methods is science mapping. Science mapping is used to investigate the structure and evolution of the focus research area (Piezunka, 2011). Science mapping uses bibliometric methods to examine how disciplines, fields, specialties, and individual writing are related to each other. Bibliometric methods allow researchers to be seen to cite and collaborate based on bibliographic data on findings and ideas produced by other scientists working in the field (Zupic, \& Čater, 2015). In other words, bibliometric methods are the process of determining the characteristic features of the publications by using mathematics and statistical analysis to obtain writers, years, subjects, countries, etc information in a certain area (Martínez, Cobo, Herrera, \& Herrera-Viedma, 2015). Bibliometric methods provide information about the structure of the area, social networks, and current interests by directing the researcher to the most effective studies and mapping the research area transparently (Zupic, \& Čater, 2015). Compared to experience-based methods, bibliometric analyzes have the advantage of collecting and processing large amounts of technical information, and the results of the analysis help researchers to explore scientific and technical texts more deeply to discover certain patterns of change (Huang, Yang, Wang, Wu, Su, \& Liang, 2019).

In the current literature, there are a limited number of systematic reviews of educational research. For example, Huang, Yang, Wang, Wu, Su, \& Liang (2019) found that by researching bibliometric analysis of educational research, it has increased over the years and the areas it covers have become larger. As a result of the research, educational researches show a certain continuity over time and through various stages (1) Interactive learning environment and "teaching/learning" strategies; (2) human capital and education finance; (3) teacher education; (4) higher education; (5) as equality and social justice found that it emerged in five main subject areas. In addition, it has shown that there are trends in interdisciplinary research, such as intelligent private lesson systems, and dyslexia which includes a combination of education and psychopathology. Apart from this, it has been observed that studies on specific topics in the field of education are carried out. These are such as management and leadership (Carreño, 2020; Hallinger, 2019; Kovačević, \& Hallinger 2019; Ozdemir, 2019), Creativity (Hernández-Torrano, \& Ibrayeva, 2020), digital competencies and computer 
skills (Stopar, \& Bartol 2019; Yalçın, \& Yayla, 2016), computer-assisted cooperative learning (Tang, Tsai, \& Lin, 2014), privatization of education (Verger, Fontdevila, Rogan, \& Gurney, 2019) and social networks and academic success (Doleck, \& Lajoie, 2018 have been conducted many bibliometric studies. However, there is no systematic study on (in)equality of opportunities in education.

Accordingly, this study aims to fill an existing gap in this field in the literature as well as providing an overview of research on (in)equality of opportunity in education by using bibliometric network analysis techniques. This research maps their discussion on (in)equality of opportunities in education and explores how a group of researchers participated in and collaborate in the debate. In other words, it tries to reveal the dynamic growth of publication and citation data of research on (in)equality of opportunity in education and the most influential writers and publications in the field. In addition, scientific collaboration networks with leading authors, institutions, and countries contributing to the field will be revealed and the most cited researchers, papers, and countries will be analyzed and the intellectual structure of the field will be drawn. For this purpose, the following questions will be tried to be answered.

What is the publishing trend of publications related to (in)equality of opportunity in education?

Which researchers institutions and universities with the cooperation contribute most to the dissemination of publications on (in)equality of opportunity in education?

What is the intellectual structure of the field of (in)equality of opportunity in education?

\section{Methodology}

In the research, bibliometric methods were used to map the scientific map of the field of (in)equality of opportunity in education. Bibliometry is a methodology used to measure scientific output by defining an area in which journal, article, or authors work (Wagner, Roessner, Bobb, Klein, Boyack, Keyton, \& Börner, 2011). Bibliometric analyses allow the researcher to identify effective researchers in the field and their relationships, providing researchers with a solid foundation for detecting new lines and trends for future studies (Avelar, Silva-Oliveira, \& Silva Pereira, 2019). Web of Science (WoS), one of the most comprehensive bibliographic databases, was used to map the literature of research on (in)equality of opportunity in education. The reason why the WoS database is preferred in bibliometric studies is that it has largely to the scientific publication network and citation data. For the current study, metadata was analyzed and downloaded from Web of Sciences (WoS) on 24 April 2020.

In the research, first of all, the literature was searched and the researches about equality of opportunity were examined and the keywords to be used in the search were determined. In the search strategy, a search was made by entering "equalit* of opportunit" or "inequalit* of opportunit" or "equal opportunit"or "inequal opportunit" or "educational equalt" or "educational inequalt" or "equalit* of educational opportunit ${ }^{* \prime}$ or "inequalit* of educational opportunit" and education*" terms without any restrictions on the subject field in the database. To reach more publications, it is used "or" conjunction between the keywords and Asterisks with wildcards at the end of the words. According to the first results, 4,967 studies on (in)equality of opportunity in education were reached. The publications were then filtered according to the research categories. It is restricted with only journal articles 
as document type, Education - Educational Research as a category, SCI-EXPANDED, SSCI, A \& HCI, ESCI as indexs. Language limitation was not applied by including the process in all years. As a result, 625 studies were obtained. The titles and summaries of these studies were analyzed and eliminated publications that the current study was not related As a result of this last operation, 505 study data remained and these were examined.

\section{Data Analysis}

VOSViewer version 1.6.9 was used to analyze the obtained data by bibliometric methods. The VOSViewer program enables the creation and viewing of bibliometric maps (Van Eck, \& Waltman, 2010). It also includes text mining techniques to create and visualize to significant terms networks exposed from the field of study (Van Eck, $\&$ Waltman, 2014). For this reason, this software was preferred for the examination and visualization of the relationship between countries, institutions and authors.

In researches on (in)equality of opportunity in education has been identified effective studies and authors and the number of citations and publications in years in order to determine the dynamic trends in the field. In the analysis were conducted to coauthorship network analyze to view the scientific cooperation networks between countries, institutions and authors. The author co-citation analysis was performed to reveal the intellectual structure of the field. The data were analyzed utilizing the full counting methodology. The full counting methodology acknowledges that each coauthor is of the same weight, regardless of the number of authors in the publication.

Co-author analysis analyzes by looking at through scientific articles to authors' collaborations (Acedo, Barroso, Casanueva, \& Galan, 2006). Since the analysis includes information about the authors' institutional relationships and geographical locations, it allows collaboration to be reviewed collaboration at institutions and countries level and reflects stronger social ties than other relevant measures (Zupic, \& Čater, 2015). In addition, the relationship between countries, research institutions or researchers shows in relation to each other depending on the number of publications they wrote together (Van Eck, \& Waltman, 2014). Therefore, it is used to examine how temporal and topological diffusion of information in scientific communities is (Chen, Chen, Horowitz, Hou, Liu, \& Pellegrino, 2009).

In co-citation analysis, it combines citations, documents, authors, or journals according to the authors' use. This analysis examines how a couple of documents, authors, or journals are cited together in a new document (Griffith, Small, Stonehill, \& Dey, 1974). In other words, the more citations a couple of documents get in a new document, the more they are linked amongst themselves, and stronger the citation power becomes (Van Eck, \& Waltman, 2014). The more frequently a publication is directed in the co-citation analysis, the more dominant it is to improve the focus area, reflecting the importance given by researchers to a cited article (Bellis, 2009).

\section{Findings}

The data obtained regarding the (in)equality of opportunity in education is firstly included in the distribution of the number of publications and citations of the articles published. Afterward, the connections of the papers, institutions, and countries in the field and co-citation network structure of the field are presented respectively. 


\section{Bibliometric Finding}

505 articles indexed in WoS about researches on (in)equality of opportunity in education were published between 1974 and 2020. Figure 1 shows the distribution of articles published between 2001 and 2020. 879 authors from 461 institutions in 66 countries were found related to (in)equality of opportunity in education.

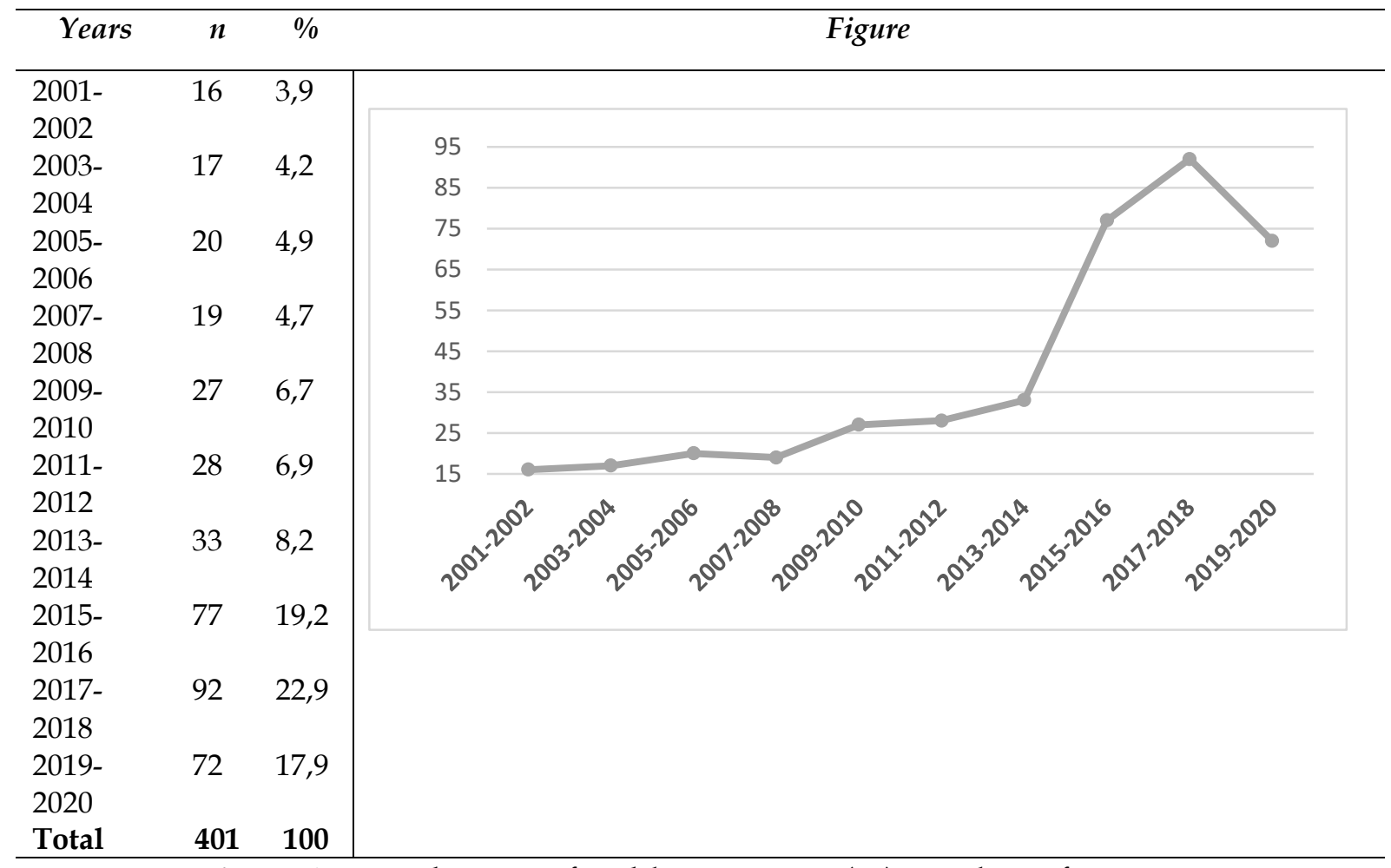

Figure 1. Distribution of publications on (in)equality of opportunity in education by year (2001-2020) Source: Web of Science, 2020)

In Figure 1, it is demonstrated appears that there are fluctuations in the distribution of articles published in the WoS database on (in)equality of opportunities in education. Publications started to rise in 2009 and increased exponentially in 2014 and beyond. In the period before 2004, publications were published on a similar number on average. Most publications were published in 2019 (57). Afterward, 50 articles were published in 2018, 42 articles in 2017 and 36 articles in 2016, respectively. 


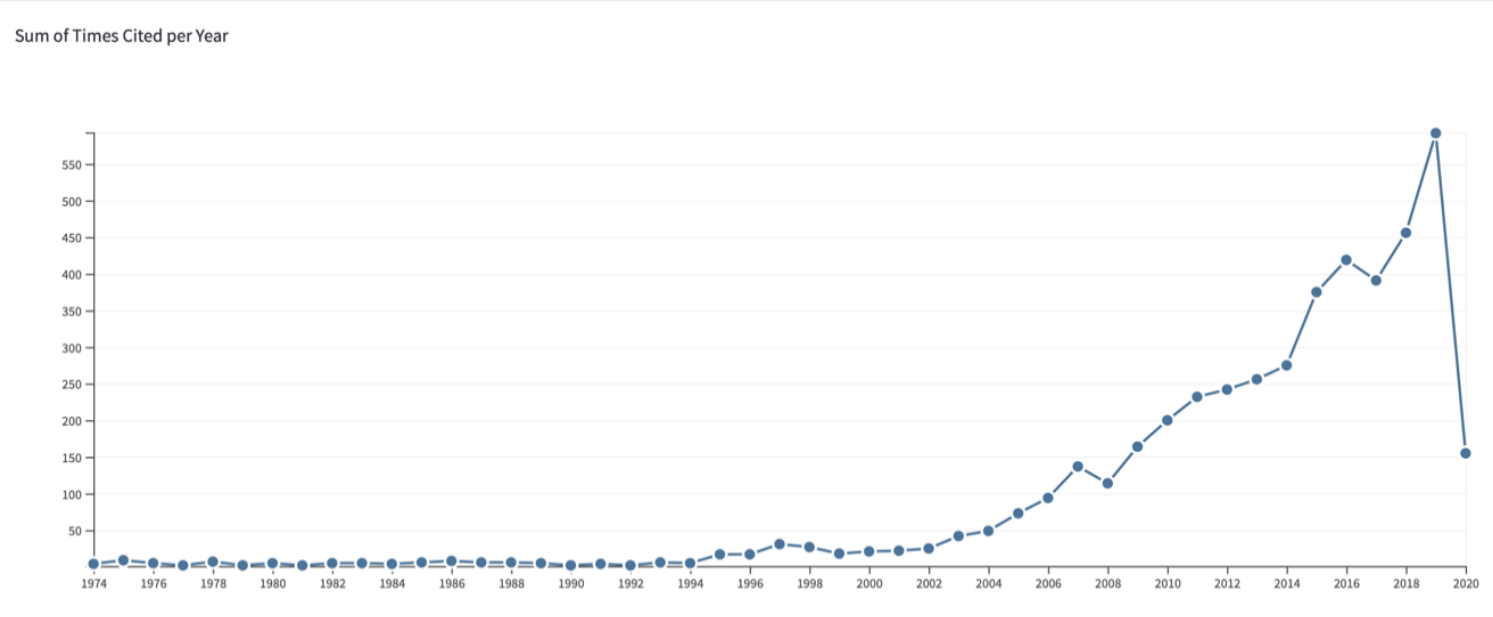

Figure 2. The number of citations of publications on (in)equality of opportunities in education by year (1974-2020) Source: Web of Science April, 2020)

In Figure 2, the number of citations referenced to publications published in the WoS database on (in)equality of opportunities in education indicates an increasing trend of citation. This shows that researchers' have an increasing impact on in the field of (in)equality of opportunities in education. When the data from 1974 to 2019 are examined, the number of citations continued increasing due to the increase in the number of publications, especially after the 2000s. The total number of citations between 1974 and 2020 is 4547. The most cited publications are 592 in 2019. 450 citation in 2018 has been realized. The number of citations before 2000 did not exceed 10. No citation has been made to the publications from 1974 to 1978.

Table 1

Top Ten Most Cited Articles Published Between 1974-2020

\begin{tabular}{|c|c|c|c|c|c|c|}
\hline & Title & Authors & Source Title & $\begin{array}{l}\text { Publication } \\
\text { Year }\end{array}$ & $\begin{array}{l}\text { Total } \\
\text { Citations }\end{array}$ & $\begin{array}{l}\text { Average } \\
\text { per } \\
\text { Year } \\
\end{array}$ \\
\hline 1 & $\begin{array}{l}\text { Maximally maintained } \\
\text { inequality - expansion, } \\
\text { reform, and opportunity in } \\
\text { irish education, } 1921-75\end{array}$ & $\begin{array}{l}\text { Raftery, } \\
\text { AE; Hout, } \\
\text { M }\end{array}$ & $\begin{array}{l}\text { Sociology of } \\
\text { Education }\end{array}$ & 1993 & 379 & 13,54 \\
\hline 2 & $\begin{array}{l}\text { Subverting Swann: First- } \\
\text { and second-generation } \\
\text { segregation in the Charlotte- } \\
\text { Mecklenburg Schools }\end{array}$ & $\begin{array}{l}\text { Mickelson, } \\
\text { RA }\end{array}$ & $\begin{array}{l}\text { American } \\
\text { Educational } \\
\text { Research } \\
\text { Journal }\end{array}$ & 2001 & 171 & 8,55 \\
\hline 3 & $\begin{array}{l}\text { Did teachers verbal-ability } \\
\text { and race matter in the 1960s } \\
\text { - coleman revisited }\end{array}$ & $\begin{array}{l}\text { Ehrenberg, } \\
\text { RG; } \\
\text { Brewer, DJ }\end{array}$ & $\begin{array}{l}\text { Economics } \\
\text { of Education } \\
\text { Review }\end{array}$ & 1995 & 122 & 4,69 \\
\hline 4 & $\begin{array}{l}\text { Expansion, differentiation, } \\
\text { and the persistence of social } \\
\text { class inequalities in British } \\
\text { higher education }\end{array}$ & $\begin{array}{l}\text { Boliver, } \\
\text { Vikki }\end{array}$ & $\begin{array}{l}\text { Higher } \\
\text { Education }\end{array}$ & 2011 & 101 & 10,1 \\
\hline 5 & $\begin{array}{l}\text { Effects of resources, } \\
\text { inequality, and privilege } \\
\text { bias on achievement: }\end{array}$ & $\begin{array}{l}\text { Chiu, Ming } \\
\text { Ming; }\end{array}$ & $\begin{array}{l}\text { American } \\
\text { Educational }\end{array}$ & 2005 & 92 & 5,75 \\
\hline
\end{tabular}




\begin{tabular}{|c|c|c|c|c|c|c|}
\hline \multirow{4}{*}{6} & $\begin{array}{l}\text { Country, school, and } \\
\text { student level analyses }\end{array}$ & $\begin{array}{l}\text { Khoo, } \\
\text { Lawrence }\end{array}$ & $\begin{array}{l}\text { Research } \\
\text { Journal }\end{array}$ & & & \\
\hline & $\begin{array}{l}\text { Educational Systems and } \\
\text { the Trade-Off between }\end{array}$ & Bol, Thijs; & & & & \\
\hline & Labor Market Allocation & Van de & Comparatıve & & & \\
\hline & $\begin{array}{l}\text { and Equality of Educational } \\
\text { Opportunity }\end{array}$ & $\begin{array}{l}\text { Werfhorst, } \\
\text { Herman G. }\end{array}$ & $\begin{array}{l}\text { Education } \\
\text { Review }\end{array}$ & 2013 & 84 & 10,5 \\
\hline \multirow[t]{4}{*}{7} & $\begin{array}{l}\text { Schools and Inequality: A } \\
\text { Multilevel Analysis of }\end{array}$ & $\begin{array}{l}\text { Borman, } \\
\text { Geoffrey }\end{array}$ & & & & \\
\hline & Coleman's Equality of & D.; & Teachers & & & \\
\hline & Educational Opportunity & Dowling, & College & & & \\
\hline & Data & Maritza & Record & 2010 & 81 & 7,36 \\
\hline \multirow[t]{2}{*}{8} & $\begin{array}{l}\text { Private tutoring and mass } \\
\text { schooling in East Asia: } \\
\text { reflections of inequality in }\end{array}$ & & Asıa Pacific & & & \\
\hline & $\begin{array}{l}\text { Japan, South Korea, and } \\
\text { Cambodia }\end{array}$ & $\begin{array}{l}\text { Dawson, } \\
\text { Walter }\end{array}$ & $\begin{array}{l}\text { Education } \\
\text { Review }\end{array}$ & 2010 & 79 & 7,18 \\
\hline 9 & $\begin{array}{l}\text { equal opportunities in } \\
\text { teacher recruitment in } \\
\text { England and Wales }\end{array}$ & $\begin{array}{l}\text { Carrington, } \\
\text { B; Skelton, } \\
\text { C }\end{array}$ & $\begin{array}{l}\text { Journal of } \\
\text { Education } \\
\text { Policy }\end{array}$ & 2003 & 70 & 3,89 \\
\hline 10 & $\begin{array}{l}\text { Serving many masters: The } \\
\text { PhD on the labour market, } \\
\text { the everlasting need of } \\
\text { inequality, and the } \\
\text { premature death of } \\
\text { humboldt }\end{array}$ & Enders, J & $\begin{array}{l}\text { Higher } \\
\text { Education }\end{array}$ & 2002 & 62 & 3,26 \\
\hline
\end{tabular}

Table 1 shows the top ten most cited articles and authors on (in)equality of opportunities in education. The citation numbers of these articles vary between 379 and 62 . The most frequently cited article in the field was published by Raftery (1993) in the Journal Sociology of Education with 379 citations. Subsequently, it was cited to Mickelson (2001) 171 citations, Ehrenberg and Brewer (1995) 122 citations, Boliver (2011) 101 citations respectively, and at the end Enders (2002) 62 citations. When the most frequently cited articles are examined, inequalities created in (in)equality and productivity by education systems and policies increase inequality in educational opportunities (Borman, \& Dowling, 2010; Bol, \& Van de Werfhorst, 2013; Dawson, 2010), and reforms in education systems was determined that It have no contribution to equalty opportunity in education (Raftery, \& Hout, 1993). In addition, in a disadvantaged school system, factors such as gender and ethnicity affect academic outcomes preventing access to learning opportunities (Carrington, \& Skelton, 2003; Ehrenberg, \& Brewer, 1995; Mickelson, 2001), and students from advantageous social class backgrounds benefit more from education. Hence, educational inequalities have been found to tend to continue (Bol, \& Van de Werfhorst, 2013; Boliver, 2011). In another study, by addressing the unequal distribution of resources it was shown that privileged students get higher scores in all subjects in exams when they have more resources in their countries, families, or schools (Chiu, \& Khoo, 2005).

\section{Co-authorship Analysis}

In Figures 3, 4, 5, and 6, they represent co-authoring networks or scientific collaboration networks in (in)equality of opportunity in education between authors, 
institutions, and countries, respectively. There are nodes and edges on the density maps. In the visual network analysis below, the node sizes indicate the number of publications belonging to the authors, the colors of the node indicate that works together of the authors, and the lines between the nodes indicates which authors are related to which authors. The color of the node demonstrates the group or cluster to which the node is existed. The smaller the distance between the nodes, the stronger the relationship between them. That is, there are more co-authoring publications among authors, institutions, or countries. In the articles published according to the coauthorship network in Figure 3, 864 authors are not related, only 15 authors are related and 18 collaboration networks have emerged. In Figure 4, visualization of the coauthorship network of the related authors is given.

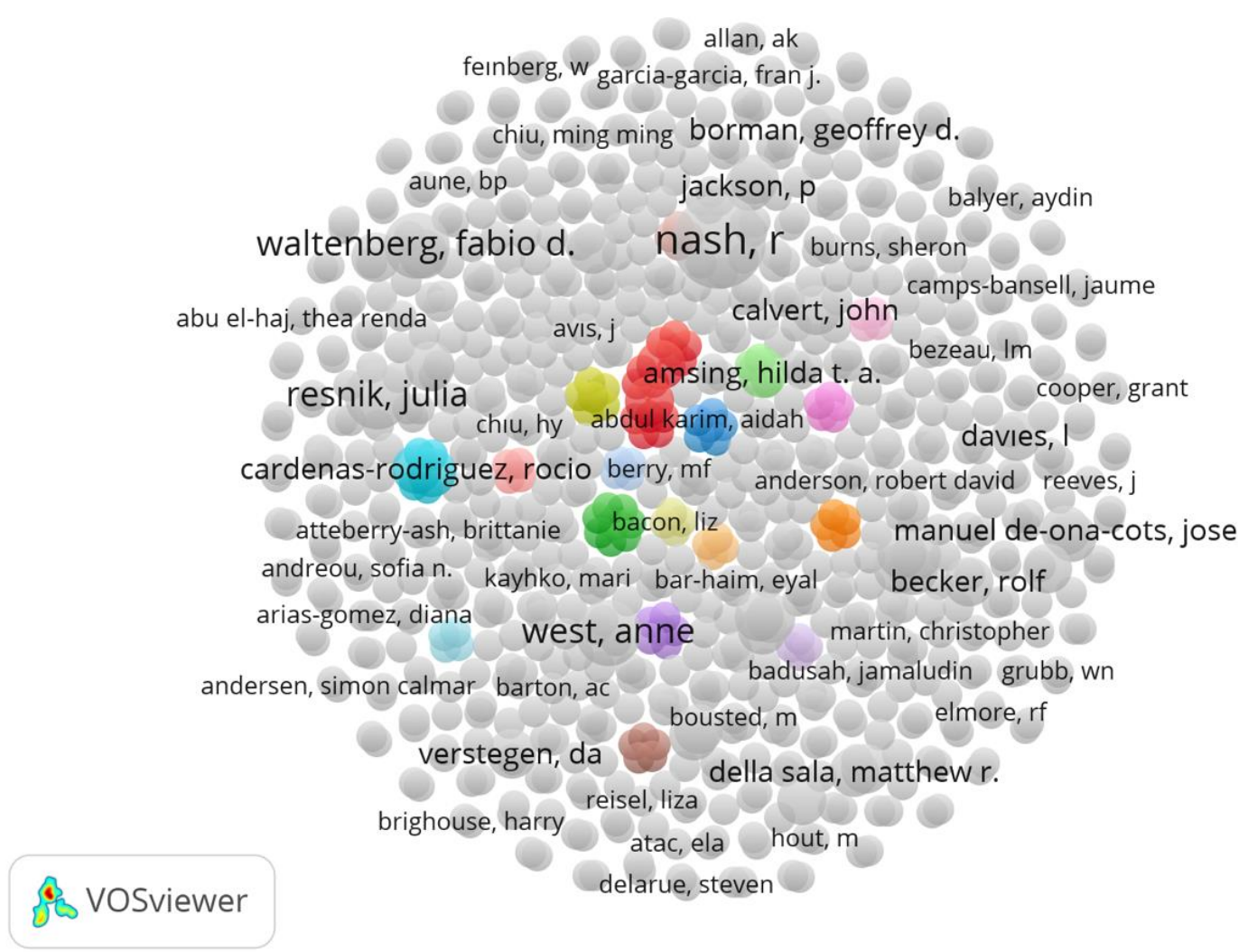

Figure 3. Co-authoring map of scientists working on (in)equality of opportunity in education (1974-2020) 


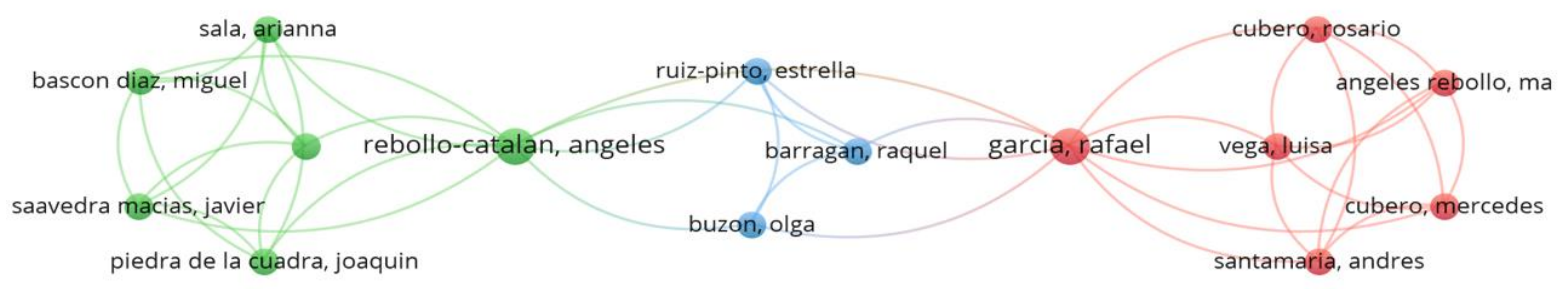

VOSviewer

Figure 4. Co-authoring map of scientists working on (in)equality of opportunity in education in education (1974-2020) (one author has at least one document)

The collaboration network of researchers with at least one publication is given in Figure 3, and 4. In Figure 3, only one of the authors has 5 publications (Roy Nash). 3 of them have 3 publications (Anne West (52 citations), Fabio D. Waltenberg (33 citations), and Julia Resnik (47 citations), 30 researchers have 2 publications and other researchers have only one publication. The author who contributed the most to (in)equality of opportunities in education is Roy Nash, with 5 publications and 85 citations.

According to figures 3 , and 4 there is little collaboration between the authors. Many authors worked independently. In the co-authorship analysis in Figure 4, of most researchers emerged 5 collaboration networks. The collaboration network is composed of three clusters. There are 9 collaboration networks, with only two authors (Garcia, \& Rebollo-Catalan) working through two cluster networks. The article titled "Teachers negotiating discourses of gender (in)equality: the case of equal opportunities reform in Andalusia" was published by 6 authors in the red cluster (Cubero, Santamaria, Rebollo, Cubero, Garcia, \& Vega, 2015). In this article, the reform made to provide equal opportunities between men and women in education in Spain has been evaluated. Their discourses on gender equality were examined with teachers responsible for the equality plan in schools brought by this reform. As a result of the research, it was found that gender inequality persists even though women have made much progress. In the green cluster, The article titled "Gender Equity in Education: Analysis and Description of Best Educational Practices" was published (RebolloCatalan, Piedra de la Cuadra, Sala, Sabuco Canto, Saavedra Macias, \& Bascon Diaz, 2012). It identifies and analyzes the best co-education practices in different school contexts in Andalucia. They found that the Equal Opportunities Plan in Andalusia 
Education has rich educational practices linked to the main drivers. They draw attention to the positive participation of teachers, parents, and school administrators in successful practices and the synergies between joint activities between the school and other institutions in the same social environment. It also highlights the key role teachers play in promoting best practices. In the blue cluster, An article titled "Technologies for coeducation and equality: teachers assessment of an educational web tool" has been published. In the red cluster, an article with 5 authors was published (Rebollo, Garcia, Barragan, Buzon, \& Ruiz-Pinto, 2012), aiming to provide teachers with a web tool to evaluate gender equality culture at school. In the research, it is aimed to provide teachers with an assessment of a web tool for evaluating the gender equality culture at school. The results reveal that there are statistically significant differences in teachers' evaluation according to their experience of using the web tool. It emphasizes the positive effects of web tools on the evaluation of positive teachers on school environment and practices.

Figure 5. Map of scientific cooperation between institutions according to coauthorship analysis (one author has at least one document)

Institutional collaboration networks are visually represented in Figure 5. On this map, five clusters have been formed in the collaboration network. In the analysis, 461 institutions were tried to be presented to be linked with each other. The cooperation network between 17 institutions that are most related is shown in Figure 6. In general, the distribution of nodes and edges indicates that institutional cooperation networks are mostly established within national borders. Most institutions are institutions in the United States. The largest collaboration network (red) represents the 7 collaboration networks, taking place at the University of Chicago (USA). He received a total of 2 articles and 28 citations. In the second cluster (blue), another network, Northwestern University (USA) received 32 citations with 5 collaboration networks. The other network of the blue cluster is the University of Wisconsin (USA). This institution has received 122 citations by creating 5 documents and 3 networks. The third group of collaborating institutions (yellow), Michigan University (USA), contains 4 articles and 4 collaboration networks and 93 citations. The fourth cluster (green) includes 93 citations, including 4 documents 4 collaboration 
networks, at Michigan State University (USA) in the United States. The fifth cluster (purple) consists of 1 document 1 collaboration network at the University of Illinois. However, there are limited research collaborations between these institutions and institutions in the United States.

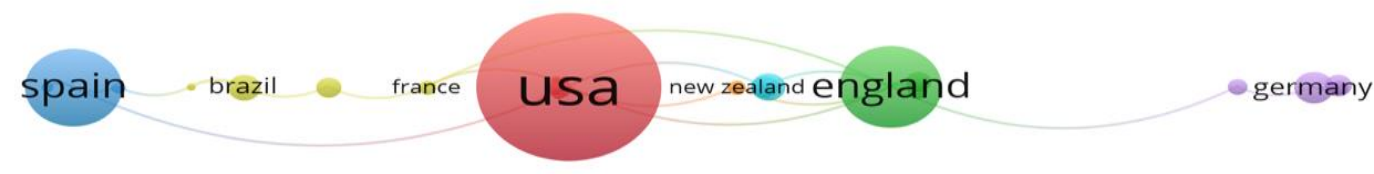

VOSviewer

Figure 6. Map of scientific cooperation among countries according to co-authorship analysis

Figure 6 represents the cooperation networks between countries in research on (in)equality of opportunity in education. Country co-authorship analysis helps to show what are the influential countries in the area and the extent of the area's spread among countries (Avelar, Silva-Oliveir, \& Silva Pereira, 2019). In this direction, countries with co-authorship networks have been tried to be determined with this analysis. As a result of the analysis, 66 countries around the world contributed to the publication of articles researches on (in)equality of opportunity in education. However, there is a cooperation between these 26 countries. The USA (105), the UK (54), and Spain (51), which have a co-authorship network is the most broadcast countries. According to the analysis presented in this study, the most productive and effective research producer in the field of (in)equality of opportunity in education is in the central position in the USA, with the first place with 105 articles and 1739 citations. Therefore, it can be said that the USA is the most productive region and that USA academics carry out more international collaborative studies. It is followed by England with 54 articles 811 citations, Spain 51 articles 117 citations and Germany 19 articles 91 citations respectively. The results show that there is little cooperation between different regions of the world. The USA, located in the red cluster in the center, has established a cooperation network with 10 countries and the strength of the connection is 11. The second country with the highest number of connections, the UK has cooperated with 9 countries and the strength of the connection is 11. Next, Spain has created 4 cooperation networks and the strength of the connection is 6 . Germany has created 3 collaborations networks and the strength of the connection is 3 . As a result, 
considering the strength and number of links of the countries, the level of cooperation seems to be weak.

\section{Co-citation Analysis}

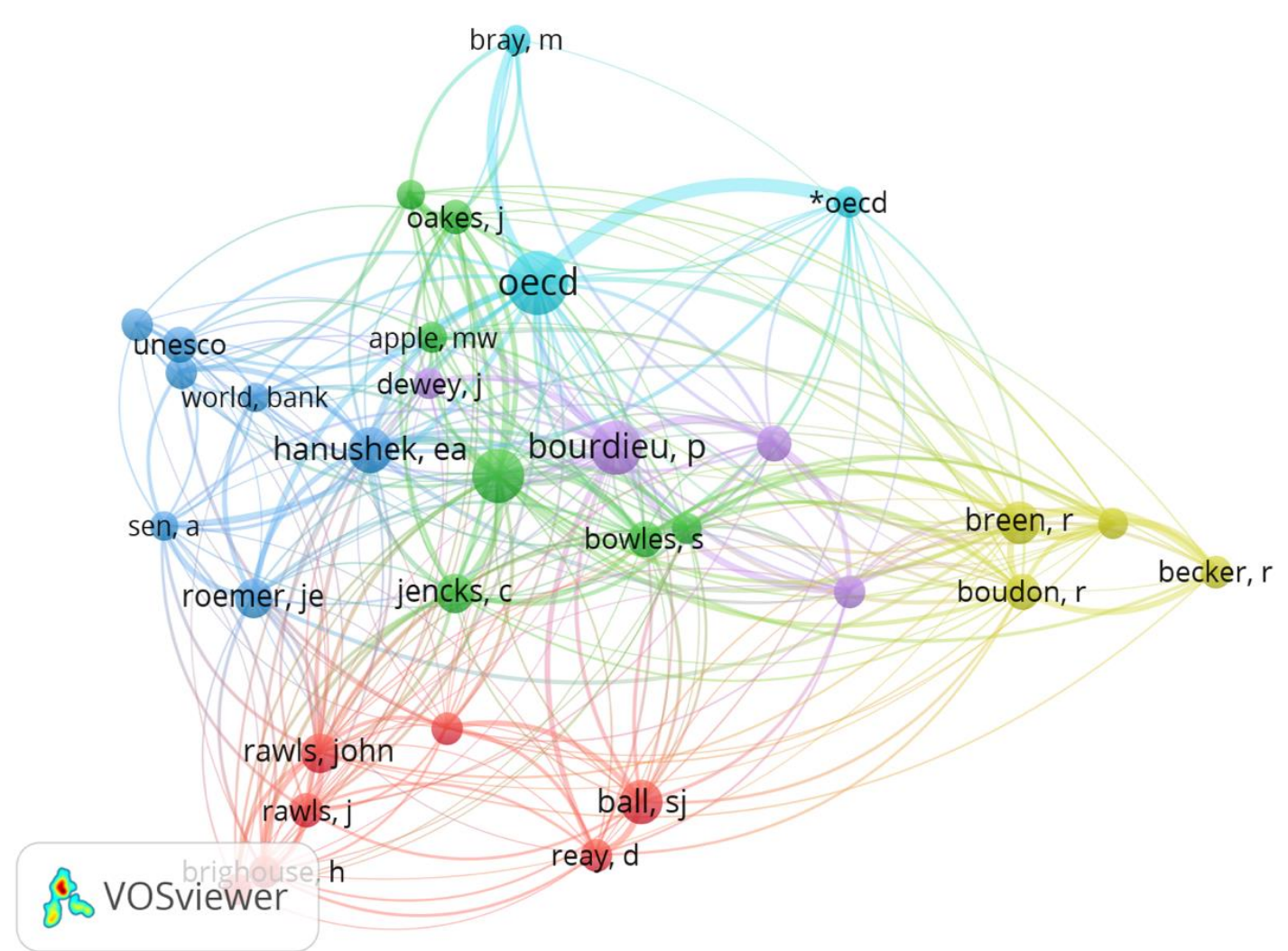

Figure 7. Map of the authors with the most citation according to author co-citation analysis (The minimum number of citations for an author is 20)

In Figure 7, a visual network analysis of the author co-citation network is presented. As a result of the analysis, 32 authors cited at least 20 times from 12921 author data are shown. The intellectual structure of (in)equality of opportunity in education consists of 6 clusters. The size of the node reflects the number of co-citations, the lines between the nodes correspond to the presence of a citation in both directions, the distance between the nodes corresponds to the tendency of the studies to be transferred together by other studies. Larger nodes show academics who have more citations and more influence. As a result of this analysis, it was revealed that the items specified were related to each other. The most co-citations author is OECD (95). Then Coleman (67), Bourdieu (67), Breen (41), Hanushek (47) respectively. Looking at these authors, it seems that they are the authors that determine the theoretical framework of the field. 


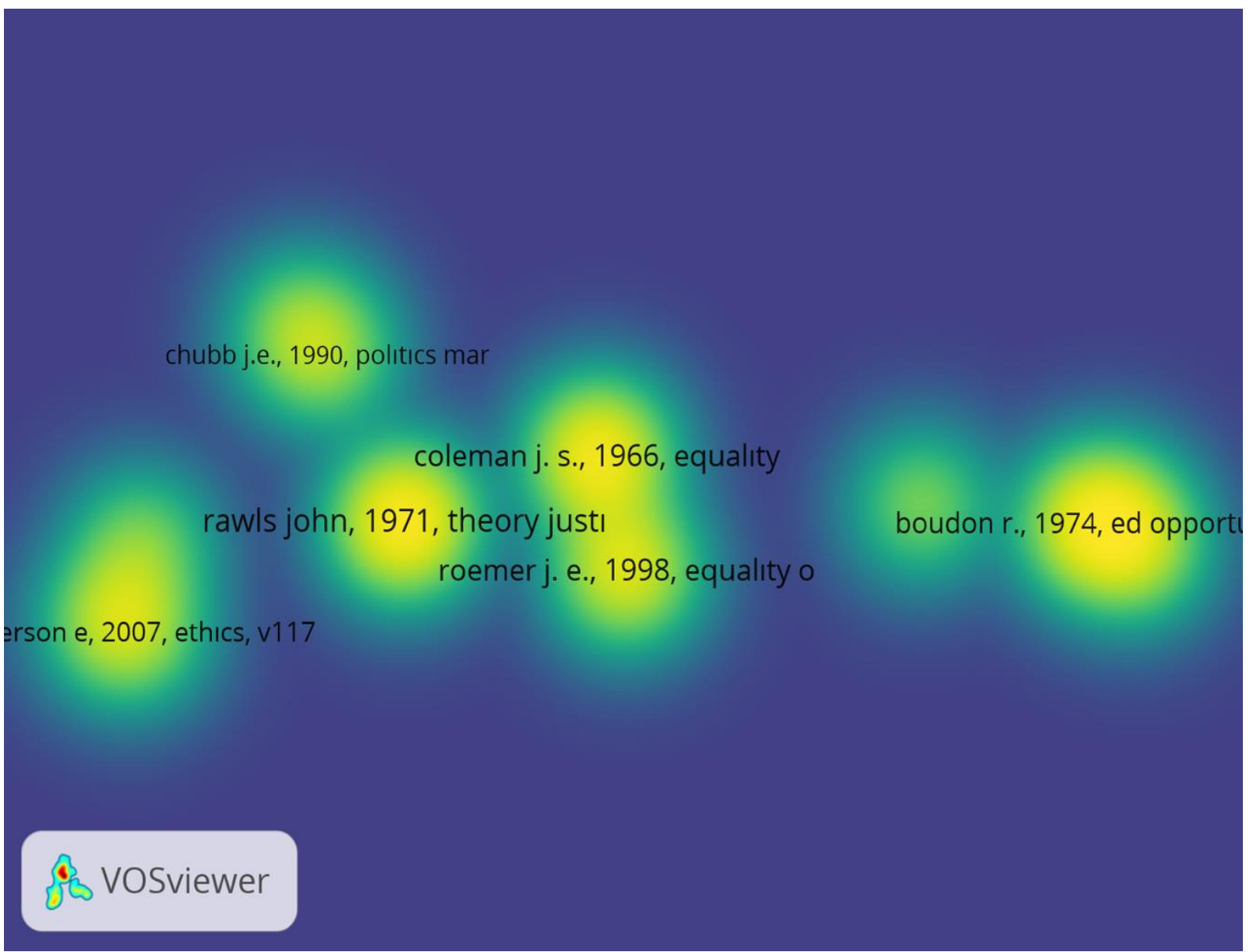

Figure 8. Densified network map of the most cited reference according to co-citation analysis (The minimum number of citations for a reference is 10)

In Figure 8, Densified visual network map of the reference co-citation network is presented. As a result of the analysis, a network map of 12 papers cited at least 10 times from 18467 references is shown. In this analysis, it was revealed that the items mentioned were related. The most co-citation paper is John Rawls's theory of justice (29). Then, respectively, Coleman's equality of educational opportunities (26), Roemer's Equality of opportunity (21), Boudon's Education, opportunity, and social inequality: Changing prospects in western society(17) are co citation papers. When these papers are examined, it is seen that they are core papers that determine the theoretical framework of the area. In Table 2, the number of citations and link strength of 12 papers is given. 
Table 2

12 Most Frequently Co-citations References

\begin{tabular}{|c|c|c|c|}
\hline & The most cited reference & Citations & Total link strength \\
\hline 1 & Rawls, J. (1971). A theory of justice, 132-80. & 29 & 28 \\
\hline 2 & $\begin{array}{l}\text { Coleman, J. S., Campbell, E., Hobson, C., McPartland, J., } \\
\text { Mood, A., \& Weinfeld, F. (1966). Equality of educational } \\
\text { opportunity study. }\end{array}$ & 26 & 12 \\
\hline 3 & $\begin{array}{l}\text { Roemer, J. E., \& Trannoy, A. (2015). Equality of } \\
\text { opportunity }\end{array}$ & 21 & 16 \\
\hline 4 & $\begin{array}{l}\text { Boudon, R. (1974). Education, opportunity, and social } \\
\text { inequality: Changing prospects in western society. }\end{array}$ & 17 & 19 \\
\hline 5 & $\begin{array}{l}\text { Shavit, Y., \& Blossfeld, H. P. (1993). Persistent inequality: } \\
\text { changing educational attainment in thirteen countries. }\end{array}$ & 12 & 13 \\
\hline 6 & $\begin{array}{l}\text { Anderson, E. (2007). Fair opportunity in education: A } \\
\text { democratic equality perspective. }\end{array}$ & 11 & 19 \\
\hline 7 & $\begin{array}{l}\text { Breen, R., \& Goldthorpe, J. H. (1997). Explaining } \\
\text { educational differentials: Towards a formal rational } \\
\text { action theory. }\end{array}$ & 11 & 18 \\
\hline 8 & $\begin{array}{l}\text { Satz, D. (2007). Equality, adequacy, and education for } \\
\text { citizenship. }\end{array}$ & 10 & 18 \\
\hline 9 & $\begin{array}{l}\text { Jencks, C. (1988). Whom must we treat equally for } \\
\text { educational opportunity to be equal?. }\end{array}$ & 10 & 13 \\
\hline 10 & $\begin{array}{l}\text { Bourdieu, P., \& Passeron, J. C. (1977). Reproduction in } \\
\text { education, culture and society. }\end{array}$ & 10 & 7 \\
\hline 11 & $\begin{array}{l}\text { Chubb, J. E., \& Moe, T. M. (1990) Politics, markets, and } \\
\text { America's schools }\end{array}$ & 10 & 6 \\
\hline 12 & $\begin{array}{l}\text { Gewirtz, S., Ball, S. J., \& Bowe, R. (1995). Markets, choice, } \\
\text { and equity in education. }\end{array}$ & 10 & 3 \\
\hline
\end{tabular}

\section{Conclusion}

In this study, the change of research trends over time-based on bibliometric methods of publications obtained from WoS between 1974-2020 regarding (in)equality of opportunity in education was investigated. As a result of the literature review, 505 articles were examined and the most cited articles, the most influential publications, and authors were determined, in addition to the distribution of the number of publications and citations by years. In addition, co-authorship analysis was carried out to establish a visual map of the cooperation network in the field, and collaborations between authors, countries, and institutions were tried to be determined. Then, in order to reveal the intellectual structure of the field, co-citation analysis was applied and the dominant writers and publications were tried to be determined.

The number of publications and citations has increased significantly over the years of research on (in)equality of opportunity in education. However, the relationship between the authors, institutions, and countries appears to be weak in the field. Most authors in the field have worked independently, and few researchers have contributed to the field by working with each other. Again, the cooperation between the institutions, depending on co-authors is observed that there is very little and is conspicuous that most of the collaborating institutions include the borders of the United States. When looking at country cooperation, it can be said that cooperation is very low. The most cooperating country the USA is in a central position by cooperating with many other countries. Most of the other cooperating countries are in different 
locations of geographical. Considering the structure of the field, co-cited writers and studies are the main sources of reference about (in)equality of opportunity in education. Since the researches in the field is carried out independently, it shows that it will be carried out in a comprehensive and cooperative future.

In the current study, where bibliometric analyzes are carried out, showing the general framework of the field, can be useful for guiding researchers in the field in their studies. However, the limitation of this research is only the review of the data in the WoS database. Although WoS is a comprehensive database, it does not contain all the publications in the field. Another limitation of the study is that only articles have been examined. In other bibliometric studies on (in)equality of opportunity in education, the field can be better understood by making it in other types of publications.

\section{References}

Acedo, F. J. Barroso, C., \& Galan, J. L. (2006). The resource-based theory: Dissemination and main trends. Strategic Management Journal, 27(7), 621-636. https:/ / doi.org/10.1002/smj.532

Anderson, E. (2007). Fair opportunity in education: A democratic equality perspective. Ethics, 17(4), 595-622. https:/ / doi.org/10.1086/518806

Arneson, R. (2009). Equality of Opportunity. Edward N. Zalta (Ed.), In the Stanford Encyclopedia of Philosophy (summer 2015 ed.), Metaphysics Research Lab.

Avelar, A. B. A., da Silva-Oliveira, K. D., \& da Silva Pereira, R. (2019). Education for advancing the implementation of the Sustainable Development Goals: A systematic approach. The International Journal of Management Education, 17(3), 100322. https:/ / doi.org/10.1016/j.ijme.2019.100322

Bellis, N. D. (2009). Bibliometrics and citation analysis: From the science citation index to Cybermetrics. Lanham: Scarecrow Press.

Bol, T., \& Van de Werfhorst, H. G. (2013). Educational systems and the trade-off between labor market allocation and equality of educational opportunity. Comparative Education Review, 57(2), 285-308. https:// doi.org/10.1086/669122

Boliver, V. (2011). Expansion, differentiation, and the persistence of social class inequalities in British higher education. Higher education, 61(3), 229-242. https:// doi.org/10.1007/s10734-010-9374-y

Bourdieu, P., \& Passeron, J. C. (1977). Reproduction in education, culture and society. London: Sage.

Borman, G., \& Dowling, M. (2010). Schools and inequality: A multilevel analysis of Coleman's equality of educational opportunity data. Teachers College Record, 112(5), 1201-1246.

Boudon, R. (1974). Education, opportunity, and social inequality: Changing prospects in western society. New York: John Wiley

Breen, R., \& Goldthorpe, J. H. (1997). Explaining educational differentials: Towards a formal rational action theory. Rationality and society, 9(3), 275-305. https:/ / doi.org/10.1177/104346397009003002

Carreño, I. D. V. G. (2020). e-Leadership: A Bibliometric Analysis. International Journal of Advanced Corporate Learning (iJAC), 13(1), 19-34. https:// doi.org/10.3991/ijac.v13i1.12341 
Carrington, B., \& Skelton, C. (2003). Re-thinking'role models': equal opportunities in teacher recruitment in England and Wales. Journal of Education policy, 18(3), 253265. https:/ / doi.org/10.1080/02680930305573

Chen, C., Chen, Y., Horowitz, M., Hou, H., Liu, Z., \& Pellegrino, D. (2009). Towards an explanatory and computational theory of scientific discovery. Journal of Informetrics, 3(3), 191-209. https://doi.org/10.1016/j.joi.2009.03.004

Chiu, M. M., \& Khoo, L. (2005). Effects of resources, inequality, and privilege bias on achievement: Country, school, and student level analyses. American Educational Research Journal, 42(4), 575-603. https:// doi.org/10.3102/00028312042004575

Coleman, J. S., Campbell, E., Hobson, C., McPartland, J., Mood, A., \& Weinfeld, F. (1966). Equality of educational opportunity study. Washington, DC: United States Department of Health, Education, and Welfare.

Coleman, J. S. (1968). Equality of educational opportunity. Integrated Education, 6(5), 19-28. https:// doi.org/10.1080/0020486680060504

Chubb, J. E., \& Moe, T. M. (1990). Politics, markets, and America's schools 1990 Washington, DC: Brookings Institution.

Cubero, M., Santamaría, A., Rebollo, M. Á., Cubero, R., García, R., \& Vega, L. (2015). Teachers negotiating discourses of gender (in) equality: the case of equal opportunities reform in Andalusia. Gender and Education, 27(6), 635-653. https:/ / doi.org/10.1080/09540253.2015.1083947

Doleck, T., \& Lajoie, S. (2018). Social networking and academic performance: A review. Education and Information Technologies, 23(1): 435-465. https:// doi.org/10.1007/s10639-017-9612-3

Dawson, W. (2010). Private tutoring and mass schooling in East Asia: Reflections of inequality in Japan, South Korea, and Cambodia. Asia Pacific Education Review, 11(1): 14-24. https:/ / doi.org/10.1007/s12564-009-9058-4

Ehrenberg, R. G., \& Brewer, D. J. (1995). Did teachers' verbal ability and race matter in the 1960s? Coleman revisited. Economics of Education Review, 14(1), 1-21. https://doi.org/10.1016/0272-7757(94)90019-1

Enders, J. (2002). Serving many masters: The PhD on the labour market, the everlasting need of inequality, and the premature death of Humboldt. Higher education, 44(3), 493-517. https:/ / doi.org/10.1023/ A:1019850524330

Feehan, P. E., Gragg II, W. L., Havener, W. M., \& Kester, D. D. (1987). Library and information science research: An analysis of the 1984 journal literature. Library $\mathcal{E}$ Information Science Research, 9(3), 173-185.

Gamoran, A., \& Long, D. A. (2006). Equality of educational opportunity: A 40 year perspective. In R. Teese, S. Lamb, \& M. Duru-Bellats (Eds.), Education and equity. Vol. 1: International perspectives on theory and policy (Chapter 1). New York, NY: Springer Press. https:/ / doi.org/10.1007/978-1-4020-5916-2_2

Gewirtz, S., Ball, S. J., \& Bowe, R. (1995). Markets, choice, and equity in education. Buckingham: Open University Press.

Griffith, B.C., Small, H.G., Stonehill, J.A. \& Dey, S. (1974). The structure of scientific literatures II: Toward a macro- and microstructure for science. Science Studies, 4 , 339-365. https:/ / doi.org/10.1177/030631277400400402 
Hallinger, P. (2019). Science mapping the knowledge base on educational leadership and management in Africa, 1960-2018. School Leadership E Management, 39(5), 537-560. https://doi.org/10.1080/13632434.2018.1545117

Jencks, C. (1988). Whom must we treat equally for educational opportunity to be equal?. Ethics, 98(3), 518-533. https://doi.org/10.1086/292969

Hanushek, E. A., \& Kain, J. F. (1972). On the value of equality of educational opportunity as a guide to public policy. On equality of educational opportunity, 116-145.

Hernández-Torrano, D., \& Ibrayeva, L. (2020). Creativity and education: A bibliometric mapping of the research literature (1975-2019). Thinking Skills and Creativity, 35, 100625. https:/ / doi.org/10.1016/j.tsc.2019.100625

Huang, C., Yang, C., Wang, S., Wu, W., Su, J., \& Liang, C. (2019). Evolution of topics in education research: a systematic review using bibliometric analysis. Educational Review,1-17.

Kovačević, J., \& Hallinger, P. (2019). Finding Europe's niche: science mapping the knowledge base on educational leadership and management in Europe, 19602018. School Effectiveness and School Improvement, 1-21. https:// doi.org/10.1080/09243453.2019.1692875

Martínez, M. A., Cobo, M. J., Herrera, M., \& Herrera-Viedma, E. (2015). Analyzing the scientific evolution of social work using science mapping. Research on Social Work Practice, 25(2), 257-277. https:/ / doi.org/10.1177/1049731514522101

McMahon, W. W. (2000). Education and development: Measuring the social benefits. London: Oxford Universty Press.

Mickelson, R. A. (2001). Subverting Swann: First-and second-generation segregation in the Charlotte-Mecklenburg schools. American Educational Research Journal, 38(2), 215-252. https:/ / doi.org/10.3102/00028312038002215

Mihai, M., Titan, E. \& Manea, D. (2015). Education and poverty. Procedia Economics and Finance, 32, 855-860. https://doi.org/10.1016/S2212-5671(15)01532-4

OECD. (2016). PISA 2015 RESULTS (VOLUME I): EXCELLENCE AND EQUITY IN EDUCATION, PISA. Paris: OECD Publishing.

OECD. (2018). Education at a Glance 2018: OECD Indicators. Paris: OECD Publishing. http:/ / dx.doi.org/10.1787/eag-2018-en.

Ozdemir, N. (2019). A bibliometric analysis of research on principal leadership and student achievement. New Trends and Issues Proceedings on Humanities and Social Sciences, 6(7), 55-61. https://doi.org/10.18844/prosoc.v6i7.4512

Rawls, J. (1971). A theory of justice. Oxford: Oxford University Press.

Peragine, V. \& Ferreira, F. (2015). Equality of opportunity: Theory and evidence. World Bank Policy Research Paper, 7217. https:/ / doi.org/10.1596/1813-9450-7217

Piezunka, H. (2011). Technological platforms: An assessment of the primary types of technological platforms their strategic issues and their linkages to organizational theory. Betriebswirtschaft, 61, 179-226. https:/ / doi.org/10.1007/s11301-011-0078-x

Raftery, A. E., \& Hout, M. (1993). Maximally maintained inequality: Expansion, reform, and opportunity in Irish education, 1921-75. Sociology of education, 4162. https:/ / doi.org/10.2307/2112784 
Rebollo, A., Garcia, R., Barragan, R., Buzon, O., \& Ruiz-Pinto, E. (2012). Technologies for coeducation and equality: teachers assessment of an educational web tool. Educacion XX1, 15(1), 87-111. https:/ / doi.org/10.5944/educxx1.15.1.151

Rebollo Catalan, M. A., Piedra de la Cuadra, J., Sala, A., Sabuco Canto, A., Saavedra Macias, J., \& Bascon Diaz, M. (2012). Gender Equity in Education: Analysis and Description of Best Educational Practices. Revista de educacion, (358), 129-152.

Roemer, J. E., \& Trannoy, A. (2015). Equality of opportunity. In Handbook of income distribution (Vol. 2, pp. 217-300). Elsevier. https://doi.org/10.1016/B978-0-44459428-0.00005-9

Satz, D. (2007). Equality, adequacy, and education for citizenship. Ethics, 117(4), 623648. https:// doi.org/10.1086/518805

Shavit, Y., \& Blossfeld, H. P. (1993). Persistent Inequality: Changing Educational Attainment in Thirteen Countries. Social Inequality Series. Boulder: Westview Press.

Stopar, K., \& Bartol, T. (2019). Digital competences, computer skills and information literacy in secondary education: mapping and visualization of trends and concepts. Scientometric, 118(2): 479-498. https://doi.org/10.1007/s11192-0182990-5

Tang, K. Y., Tsai, C. C., \& Lin, T. C. (2014). Contemporary intellectual structure of CSCL research (2006-2013): A co-citation network analysis with an education focus. International Journal of Computer-Supported Collaborative Learning, 9(3), 335-363. https:/ / doi.org/10.1007/s11412-014-9196-5

Ünal, L. I. \& Özsoy, S. (1999). Modern Türkiye'nin Sisyphos miti: Eğitimde fırsat eşitliği. F. Gök (Ed.), 75.Yılda Eğitim (ss. 39-72). İstanbul: Türkiye Ekonomik ve Toplumsal Tarih Vakfı Bilanço'98 Yayın Dizisi.

Van Eck, N., \& Waltman, L. (2010). Software survey: VOSviewer, a computer program for bibliometric mapping. Scientometrics, 84(2), 523-538. https:/ / doi.org/10.1007/s11192-009-0146-3

Van Eck, N. J., \& Waltman, L. (2014). Visualizing bibliometric networks. In Measuring scholarly impact (pp. 285-320). Springer, Cham. https://doi.org/10.1007/978-3319-10377-8_13

Verger, A., Fontdevila, C., Rogan, R., \& Gurney, T. (2019). Manufacturing an illusory consensus? A bibliometric analysis of the international debate on education privatisation. International Journal of Educational Development, 64, 81-95. https:// doi.org/10.1016/j.ijedudev.2017.12.011

Wagner, C. S., Roessner, J. D., Bobb, K., Klein, J. T., Boyack, K. W., Keyton, J., ... \& Börner, K. (2011). Approaches to understanding and measuring interdisciplinary scientific research (IDR): A review of the literature. Journal of informetrics, 5(1), 14-26. https://doi.org/10.1016/j.joi.2010.06.004

Woessmann, L. (2004). How equal are educational opportunities? Family background and student achievement in Europe and the US. (March 2004). CESifo Working Paper Series No. 1162. Available at SSRN: https:/ / ssrn.com/abstract=528209

Yalçın, H., \& Yayla, K. (2016). Scientometric Analysis of the Researches About Technological Pedagogical Content Knowledge and Scholarly

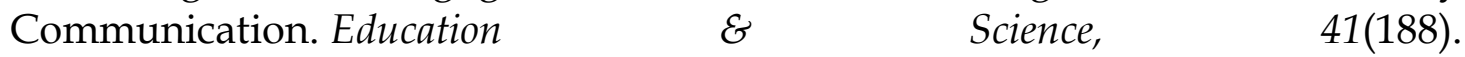
https:// doi.org/10.15390/EB.2016.6746 
Zupic, I., \& Čater, T. (2015). Bibliometric methods in management and organization. Organizational Research Methods, 18(3), 429-472. https:// doi.org/10.1177/1094428114562629

\section{Araştırmanın Etik İzinleri}

Yapılan bu çalışmada "Yükseköğretim Kurumları Bilimsel Araştırma ve Yayın Etiği Yönergesi" kapsamında uyulması belirtilen tüm kurallara uyulmuştur. Yönergenin ikinci bölümü olan "Bilimsel Araştırma ve Yayın Etiğine Aykırı Eylemler" başlı̆̆ı altında belirtilen eylemlerden hiçbiri gerçekleştirilmemiştir.

Etik kurul izin bilgileri

Etik değerlendirmeyi yapan kurul ad 1 = Atatürk Üniversitesi Sosyal ve Beşeri Bilimler Etik Kurulu Eğitimbilimleri Birim Etik Kurul Başkanlığ1

Etik değerlendirme kararının tarihi $=6.05 .2020$

Etik değerlendirme belgesi sayı numarası $=08 / 07$

\section{Authors' Biodata/ Yazar Bilgileri}

Mücella Savaş Yalçın works as a research assistant at the department of Educational Administration at Atatürk University. She is a PhD student at Hacettepe University, Institute of Educational Sciences. She continues her studies in the field of education administration and education policies.

Mücella SAVAŞ YALÇIN Atatürk Üniversitesi Kazım Karabekir Eğitim Fakültesi, Eğitim Yönetimi Anabilim Dalında araştırma görevlisi olarak görev yapmaktadır. Hacettepe Üniversitesi Eğitim Bilimleri Enstitüsünde doktora öğrencisidir. Eğitim yönetimi ve eğitim politikaları alanında çalışmalarını sürdürmektedir.

Didem Koşar is a faculty member at the Department of Educational Administration, Faculty of Education at Hacettepe University. She has a deal of papers in national and international congresses and journals.

Didem KOŞAR Hacettepe Üniversitesi Eğitim Fakültesi Eğitim Yönetimi Anabilim Dalında öğretim üyesidir. Ulusal ve uluslararası kongre ve dergilerde çok sayıda bildirisi ve makaleleri bulunmaktadır. 